\title{
Risk factors for Toxoplasma gondii infection in sheep in the northeastern region of Brazil
}

\section{Fatores de risco para a infecção de Toxoplasma gondii em ovinos da região nordeste do Brasil}

\author{
Huber RIZZO루 Natália Carrillo GAETA²; João Henrique Costa HORA³; Jeferson Silva CARVALHO ${ }^{1}$; \\ José Wilton PINHEIRO JÚNIOR ${ }^{1}$; Solange Maria GENNARI ${ }^{4}$; Hilda Fátima de Jesus PENA ${ }^{4}$; \\ Eliana Monteforte Cassaro VILLALOBOS 5 ; Lilian GREGORY ${ }^{2}$ \\ ${ }^{1}$ Universidade Federal Rural de Pernambuco, Departamento de Medicina Veterinária, Recife - PE, Brazil \\ ${ }^{2}$ Universidade de São Paulo, Faculdade de Medicina Veterinária e Zootecnia, Departamento de Clínica Médica, São Paulo - SP, Brazil \\ ${ }^{3}$ Independent veterinarian, Aracajú - SE, Brazil \\ ${ }^{4}$ Universidade de São Paulo, Faculdade de Medicina Veterinária e Zootecnia, Departamento de Medicina Veterinária Preventiva \\ e Saúde Animal, São Paulo - SP, Brazil \\ ${ }^{5}$ Instituto Biológico, Secretaria da Agricultura e Abastecimento, Laboratório de Raiva e Encefalites, São Paulo - SP, Brazil
}

\begin{abstract}
Toxoplasma gondii is an infective parasite that causes reproductive disorders such as abortion, fetal mummification, birth of weak offspring, and stillbirth, thereby causing economic losses to sheep production. The northeastern region of Brazil has approximately 171 million small ruminants, of which $5.4 \%$ are sheep. The present study aimed at determining the rate of occurrence of T. gondii in sheep flocks on 60 farms in 19 municipalities in the three mesoregions (eastern, semi-arid, and sertão or backlands) of the state of Sergipe, Brazil, and the risk factors associated with this infection. Serum samples were collected between 2011 and 2012, from 60 farms located in 19 municipalities in the three mesoregions: 680 in the eastern region, 280 in the semi-arid region, and 240 in the backlands, totaling 1,200 samples (990 females and 210 males). Anti- $T$. gondii antibodies were detected by means of the indirect fluorescence antibody test (IFAT $\geq 64$ ). The highest occurrence was detected in the eastern region $(45.3 \%, \mathrm{p}=0.001)$. On farms with subsistence production, the risk of having animals infected by T. gondii was approximately twice as high as on breeding/rebreeding/fattening farms (OR: 3.03; CI: 1.97-4.68). There was a significant lack of sanitary care, such as absence of a dunghill ( $\mathrm{p}=0.000$; OR: 1.60; CI: 1.26-2.03), quarantine ( $\mathrm{p}=0.000$; OR: 1.87; CI: 1.45-2.41) and disinfection ( $\mathrm{p}=0.003$; OR: 1.46; CI: 1.13-1.88). Regarding feeding, the risk of infection was 1.74 and 1.37 times higher in places that used a trough and/or that cats could access, respectively. The present study allows the conclusions that T. gondii is found on farms in the three mesoregions of the state of Sergipe and that environmental and management factors have an influence on sheep infection.
\end{abstract}

Keywords: Abortion. Oocyst. Sheep breeding. Parasitology. Toxoplasmosis.

\section{Resumo}

Toxoplasma gondii é um parasita cuja infecção leva a desordens reprodutivas como aborto, mumificação fetal, nascimento de cordeiros fracos e natimortos, provocando perdas econômicas na produção ovina. A região nordeste do Brasil possui aproximadamente 171 milhões de pequenos ruminantes, dos quais 5,4\% são ovinos. Este estudo tem como objetivo determinar a ocorrência de T. gondii nos rebanhos ovinos de 60 propriedades de 19 municípios de três mesorregiões (leste, semiárido e sertão) do estado de Sergipe, Brasil, e os fatores de risco associados a essa infecção. Amostras de soro foram coletadas entre 2011 e 2012, em 60 propriedades localizadas em 19 municípios das três mesorregiões: 680 na região leste, 280 no semiárido e 240 no sertão, totalizando 1.200 amostras (990 fêmeas e 210 machos). Anticorpos anti-T.gondii foram detectados por reação de imunofluorescência indireta (RIF $\geq 64)$. A maior ocorrência foi detectada na região leste $(45,3 \%, \mathrm{p}=0.001)$. Em propriedades com produção de subsistência, o risco de animais infectados por T. gondii é aproximadamente duas vezes maior que nas de cria/recria/engorda $(\mathrm{OR}=3.03 /$ IC: 1.97-4.68). A ausência de cuidados sanitários, como ausência de esterqueira ( $\mathrm{p}=0.000$ / OR: 1.60; CI: 1.26-2.03); quarentena ( $\mathrm{p}=0.000$ / OR: 1.87; CI: 1.45-2.41) e desinfecção ( $\mathrm{p}=0.003$ / OR: 1.46; CI: 1.13-1.88) foram significantes. Em relação à alimentação, o risco de infecção aumenta 1.74 e 1.37 em locais que utilizam cocho ou com presença de gatos, respectivamente. Este estudo permite concluir que o T. gondii é encontrado em propriedades das mesorregiões do estado de Sergipe e fatores ambientais e de manejo estão influenciando nas infecções em ovinos.

Palavras-chave: Aborto. Oocisto. Criação de ovinos. Parasitologia. Toxoplasmose. 
Correspondence to:

Natália Carrillo Gaeta

Universidade de São Paulo, Faculdade de Medicina Veterinária

e Zootecnia, Departamento de Clínica Médica

CEP 05508-270, São Paulo, SP, Brazil

e-mail: natalia.gaeta@hotmail.com

Received: $19 / 07 / 2016$

Approved: 12/05/2017

\section{Introduction}

Toxoplasmagondii is a parasitein the phylum Apicomplexa. Felids are its definitive host and homoeothermic animals are its intermediate host. Transmission can occur through ingestion of food or water contaminated with oocysts, by eating raw or undercooked meat or by means of the transplacental route, in which tachyzoites can infect fetuses (FRENKELL, 1990; SILVA; LA RUE, 2006).

Infection by T. gondii is mostly present in areas with warm and wet weather (DUBEY, 2009). Sporulation of oocysts and their survival in the environment occur only under favorable conditions, such as proper aeration and suitable humidity and temperature. Under such conditions, oocysts become infective within five days (TENDER et al., 2000).

In relation to sheep production, $T$. gondii infection causes reproductive disorders (MILLAR et al., 2007), such as abortion, fetal mummification, birth of weak lambs, and stillbirth, thereby causing economic losses. One of the few studies that conducted an economic analysis of these losses, Freyre et al. (1999), reported losses of between 1.4 and 4.7 million dollars, in Uruguay.

In Brazil the reported prevalence of T. gondii among sheep has ranged from $25.75 \%$ to $80 \%$ (OGAWA et al., 2003; FIGLIUOLO et al., 2004; UENO et al., 2009; ROSSI et al., 2011Minas Gerais State, Brazil, this study aimed to investigate the frequency of antibodies against these parasites in sheep sera from this region by using different serological methods. A total of 155 sheep serum samples were analyzed by the indirect fluorescence antibody test (IFAT; TESOLINI et al., 2012; MENDONÇA et al., 2013).

The northeastern region of Brazil has approximately 171 million small ruminants, of which 5.4\% are sheep (IBGE, 2011). The seroprevalence in this area is between $11.11 \%$ and 48.4\% (BISPO et al., 2011; MENDONÇA et al., 2013; CORREIA et al., 2015), and the risk factors associated with the infection have been water supply (BRANDÃO et al., 2009), sex and breed (SILVA et al., 2003), age, presence of cats, and water source (ANDRADE et al., 2013). The state of Sergipe has $1 \%$ of the total number of small ruminants in the northeastern region, and its total sheep flock is approximately 168,801 . Antibodies against $T$. gondii were only described in sheep flocks by Mendonça et al. (2013), whose study revealed $28.22 \%$ of serum-reactive samples. Regarding other species, evidence of T. gondii infection was detected in wild animals (53.1\%) (PIMENTEL et al., 2009).

Since T. gondii infection is one of the most important causes of reproductive disorders in sheep flocks, its prevalence needs to be more thoroughly understood. Therefore, the present study aimed at determining the prevalence of T. gondii in sheep flocks of 60 farms in the three mesoregions of the state of Sergipe and the risk factors associated with infection.

\section{Material and Methods}

This study was conducted within the standards established by the Bioethics Committee of the "Pius X" School, in Aracajú, Sergipe, Brazil (approval no. 06/2014).

The state of Sergipe is located between the latitudes $9^{\circ} 30^{\prime} 49^{\prime \prime}$ and $11^{\circ} 34^{\prime} 05^{\prime \prime}$ and the longitudes $36^{\circ} 23^{\prime} 4^{\prime \prime}$ and $\left.38^{\circ} 15^{\prime} 00^{\prime \prime}\right)$. Its territorial area is $21.915 \mathrm{~km}^{2}$ and it is divided into three edaphoclimatic mesoregions: eastern region, semi-arid region, and backlands (SANTOS et al., 2014). Sergipe holds $1 \%$ of the small ruminant flock of northeastern Brazil, comprising a total of 170.547, of which $89.24 \%$ are sheep (SEBRAE, 2011).

Municipalities and farms were selected according to the state divisions and according to convenience, easiness of access and availability of producers. Animals were randomly selected. Healthy male and female sheep, with different husbandry standards (pure breed, half-breed, and mixed breed) older than six months of age were enrolled into this study.

Samples were collected between 2011 and 2012 from 60 farms located in 19 municipalities in the three mesoregions: 680 in the eastern region, 280 in semi-arid region, and 240 in the backlands - thus total of 1,200 serum samples ( 990 females and 210 males), 20 from each farm.

An epidemiological interview was conducted on each farm, in order to evaluate the risk factors associated with T. gondii infection. This interview consisted of closed questions related to the farm: mesoregion (eastern, semi-arid, or backland region), production system (extensive, intensive, or semi-extensive), terrain (rough, waterlogged, or flat), installations (pens with cemented, unpaved, or slatted floor), food storage accessibility to cats, availability of food (covered trough or uncovered 
trough) and water source accessibility to cats. There was also one question related to herd features: purpose of the animal production (breeding/rebreeding, fattening, reproduction, or subsistence). There were also questions relating to management: water source (running, standing, or standing + running), water supply (from the source, containers inside the facility, containers inside and outside the facility, or containers outside the facility); disinfection of installations, use of a dunghill, food storage (uncovered place, covered place, or both), quarantine and presence of sheep with reproductive disorders.

Blood samples were collected via jugular vein puncture using a vacuum tube, without anticoagulant. The samples were centrifuged at $1,600 \mathrm{~g}$ for 10 minutes. The resultant serum samples were identified and stored at $-20^{\circ} \mathrm{C}$.

Samples were tested for antibodies to T. gondii by means of indirect fluorescence antibody test (IFAT), as described by Camargo (1974), with a cut-off point of 1:64 (GARCIA et al., 1999). Tachyzoites of $T$. gondii from the RH reference strain, cultured in Vero cells, were methanol fixed in slides as the antigen.
All the statistical calculations were performed using the EpiInfo 3.5.1 statistical package and a 95\% confidence interval (CI). Descriptive analysis was performed to determine absolute and relative frequencies. Data were analyzed by means of Pearson's chi-square test or Fisher's exact test in the form of univariate analysis to study risk factors associated with infection by $T$. gondii. Logistic regression was used, taking the IFAT results (reactive or non-reactive) to be a dependent variable relating to the infection. In order to avoid exclusion of important risk factors, independent variables with statistical significance less than or equal to $20 \%$ were selected for the model (HOSMER; LEMESHOW, 1989).

\section{Results}

The rate of occurrence of antibodies against $T$. gondii was $93.3 \%$ at herd level and $40.1 \%$ at animal level. The highest prevalence was detected in the eastern region $(p=0.001)$, where the two municipalities with the highest frequencies were located: Divina Pastora and Arauá (73.3\% and $71.7 \%$, respectively). Table 1 presents the prevalence values for antibodies against $T$. gondii per municipality.

Table 1 - Occurrences of antibodies against Toxoplasma gondii detected by means of indirect fluorescence antibody test $(\geq 64)$ on sheep serum samples, according to farm, animal, and region - Sergipe 2011-2012

\begin{tabular}{lcc}
\hline & \multicolumn{2}{c}{ Farms Animals } \\
\cline { 2 - 3 } \multicolumn{1}{c}{ Municipality } & Positive/total (\%) & Positive/total (\%) \\
\hline Aracaju & $1 / 1(100)$ & $13 / 20(65.0)$ \\
Arauá & $3 / 3(100)$ & $43 / 60(71.7)$ \\
Boquim & $1 / 1(100)$ & $9 / 20(45.0)$ \\
Divina Pastora & $3 / 3(100)$ & $44 / 60(73.3)$ \\
Estância & $4 / 4(100)$ & $32 / 80(40.0)$ \\
Itabaianinha & $9 / 9(100)$ & $82 / 180(45.6)$ \\
Itaporanga d'ajuda & $4 / 5(80)$ & $38 / 100(38.0)$ \\
Maruim & $2 / 2(100)$ & $8 / 40(20.0)$ \\
Nossa Senhora do Socorro & $1 / 1(100)$ & $5 / 20(25.0)$ \\
Salgado & $3 / 3(100)$ & $23 / 60(38.3)$ \\
São Cristóvão & $1 / 2(50)$ & $11 / 40(27.5)$ \\
Total for eastern region & $32 / 34(94.1)$ & $308 / 680(45.3)$ \\
Cumbe & $1 / 1(100)$ & $4 / 20(20.0)$ \\
Lagarto & $6 / 6(100)$ & $44 / 120(36.7)$ \\
Nossa Senhora das Dores & $4 / 4(100)$ & $35 / 80(43.8)$ \\
Simão Dias & $2 / 3(66.7)$ & $12 / 60(20.0)$ \\
Total for semi-arid region & $13 / 14(92.9)$ & $95 / 280(33.9)$ \\
Canindé de São Francisco & $4 / 4(100)$ & $9 / 80(11.3)$ \\
Feira Nova & $2 / 2(100)$ & $20 / 40(50.0)$ \\
Itabi & $1 / 2(50)$ & $11 / 40(27.5)$ \\
Nossa Senhora da Glória & $4 / 4(100)$ & $38 / 80(47.5)$ \\
Total for backlands region & $11 / 12(91.7)$ & $781 / 240(32.5)$ \\
Total & $56 / 60(93.3)$ & \\
\hline & & $(40.1)$ \\
\hline
\end{tabular}


The antibody titers detected were: 4096 (0.2\%), 2048 (1.5\%), 1024 (2.7\%), 512 (3.3\%), 128 (3.7\%), 256 (5.2\%), and $64(83.4 \%)$. In the semi-arid region, only titers of 64 and 128 were detected (Table 2).

Table 3 presents the odds' ratio and chi-square analyses. The variables of mesoregion, purpose of production system, terrain, disinfection of installations, use of dunghill, availability of food, food storage accessibility to cats, and quarantine were selected for the multivariate analyses.

The statistical significance observed in multivariate logistic regression is described in Table 4. In subsistence farms, the risk of having animals infected by T. gondii was approximately twice as high as in breeding/rebreeding/ fattening farms ( $\mathrm{p}=0.000$; OR: 3.03; CI: 1.97-4.68). Farms in the eastern region with waterlogged ( $p=0.005$; OR: 1.81 ; CI: 1.19-2.77) and semi-extensive production systems ( $p=0.012$; OR: 1.90; CI: 1.01-3.74) had the highest chance of having infected sheep. Lack of sanitary care, such as absence of a dunghill ( $\mathrm{p}=0.000$; OR: 1.60; CI: 1.26-2.03), quarantine $(\mathrm{p}=0.000$; OR: 1.87 ; CI: 1.45-2.41) and disinfection ( $p=0.003$; OR: 1.46; CI: 1.13-1.88) were important for the infection. Regarding feeding, the risk of infection was 1.74 and 1.37 times higher in places that used a trough and/or which cats could access, respectively $(\mathrm{p}<0.05)$.

Table 2 - Frequency of antibody titers against Toxoplasma gondii determined by means of indirect fluorescence antibody test on sheep serum samples, according to region - Sergipe - 2011-2012

\begin{tabular}{lcccccccc}
\hline \multirow{2}{*}{ Region } & \multicolumn{7}{c}{ Positive samples (\%) } \\
\cline { 2 - 8 } & $\mathbf{6 4}$ & $\mathbf{1 2 8}$ & $\mathbf{2 5 6}$ & $\mathbf{5 1 2}$ & $\mathbf{1 0 2 4}$ & $\mathbf{2 0 4 8}$ & $\mathbf{4 0 9 6}$ & Total (\%) \\
\hline Eastern & $251(52.2)$ & $13(2.7)$ & $17(3.5)$ & $11(2.3)$ & $8(1.7)$ & $7(1.5)$ & $1(0.2)$ & $308(64.0)$ \\
Semi-arid & $73(15.2)$ & $4(0.8)$ & $8(1.7)$ & $5(1.04)$ & $5(1.04)$ & - & - & $95(19.8)$ \\
Backlands & $77(16.0)$ & $1(0.2)$ & - & - & - & - & - & $78(16.2)$ \\
Total & $401(83.4)$ & $18(3.7)$ & $25(5.2)$ & $16(3.3)$ & $13(2.7)$ & $7(1.5)$ & $1(0.2)$ & $481(100)$ \\
\hline
\end{tabular}

Table 3 - Risk factors associated with infection by Toxoplasma gondii in sheep flocks in the eastern, semi-arid and backlands regions - Sergipe - 2011-2012

\begin{tabular}{|c|c|c|c|c|}
\hline Variable & Examined & Positive (\%) & OR $(95 \% \mathrm{Cl})$ & p-value \\
\hline \multicolumn{5}{|l|}{ Mesoregion } \\
\hline Semi-arid & 280 & $95(33.9)$ & - & \multirow{3}{*}{0.000} \\
\hline Eastern & 680 & $308(45.3)$ & $1.61(1.20-2.18)$ & \\
\hline Backlands & 240 & $78(32.5)$ & $0.58(0.42-0.80)$ & \\
\hline \multicolumn{5}{|l|}{ Sex } \\
\hline Female & 989 & $404(40.8)$ & \multirow{2}{*}{$1.20(0.87-1.65)$} & \multirow{2}{*}{0.136} \\
\hline Male & 211 & $77(36.5)$ & & \\
\hline \multicolumn{5}{|l|}{ Breed } \\
\hline Dorper & 72 & $30(41.7)$ & - & \multirow{3}{*}{0.284} \\
\hline Mixed & 65 & $20(30.8)$ & $0.62(0.29-1.33)$ & \\
\hline Santa Inês & 1063 & $431(40.5)$ & $1.53(0.87-2.78)$ & \\
\hline \multicolumn{5}{|l|}{ Purpose of production } \\
\hline Breeding/rebreeding/fattening & 960 & $352(36.7)$ & - & \multirow{3}{*}{0.000} \\
\hline Reproduction & 140 & $64(45.7)$ & $1.45(1.00-2.11)$ & \\
\hline Subsistence & 100 & $65(65.0)$ & $2.21(1.26-3.88)$ & \\
\hline \multicolumn{5}{|l|}{ Production system } \\
\hline Extensive & 500 & $218(43.6)$ & - & \multirow{3}{*}{0.012} \\
\hline Intensive & 60 & $15(25.0)$ & $0.43(0.22-0.81)$ & \\
\hline Semi-extensive & 640 & $248(38.8)$ & $1.90(1.01-3.74)$ & \\
\hline \multicolumn{5}{|l|}{ Terrain } \\
\hline Rough & 120 & $36(30.0)$ & - & \multirow{3}{*}{0.010} \\
\hline Waterlogged & 580 & $254(43.8)$ & $1.82(1.17-2.86)$ & \\
\hline Flat & 500 & $191(38.2)$ & $0.79(0.62-1.02)$ & \\
\hline \multicolumn{5}{|l|}{ Installations } \\
\hline Cemented pen floors & 120 & $53(44.2)$ & - & \multirow{3}{*}{0.077} \\
\hline Unpaved pen floors & 540 & $196(36.3)$ & $0.72(0.47-1.10)$ & \\
\hline Slatted pen floors & 420 & $179(42.6)$ & $1.30(1.00-1.71)$ & \\
\hline \multicolumn{5}{|l|}{ Disinfection of installations } \\
\hline Yes & 580 & $205(35.3)$ & \multirow{2}{*}{$0.68(0.53-0.85)$} & \multirow{2}{*}{0.001} \\
\hline No & 620 & $276(44.5)$ & & \\
\hline
\end{tabular}


Table 3 - Continuation

\begin{tabular}{|c|c|c|c|c|}
\hline Variable & Examined & Positive (\%) & OR $(95 \% \mathrm{Cl})$ & p-value \\
\hline \multicolumn{5}{|l|}{ Use of dunghill } \\
\hline Yes & 540 & $183(33.9)$ & \multirow{2}{*}{$0.62(0.49-0.78)$} & \multirow{2}{*}{0.000} \\
\hline No & 660 & $298(45.2)$ & & \\
\hline \multicolumn{5}{|l|}{ Food storage } \\
\hline Uncovered & 100 & $32(32.0)$ & - & \multirow{3}{*}{0.345} \\
\hline Covered & 920 & $354(38.5)$ & $1.33(0.84-2.14)$ & \\
\hline Uncovered and covered & 20 & $6(30.0)$ & $0.69(0.21-1.92)$ & \\
\hline \multicolumn{5}{|l|}{ Cat access to food storage } \\
\hline Yes & 280 & $129(46.1)$ & \multirow{2}{*}{$1.37(1.05-1.80)$} & \multirow{2}{*}{0.011} \\
\hline No & 920 & 352 (383.) & & \\
\hline \multicolumn{5}{|l|}{ Availability of food } \\
\hline Covered trough & 640 & $209(32.7)$ & \multirow{2}{*}{$0.57(0.43-0.74)$} & \multirow{2}{*}{0.000} \\
\hline Uncovered trough & 360 & $165(45.8)$ & & \\
\hline \multicolumn{5}{|l|}{ Water supply } \\
\hline From the source & 440 & $181(41.1)$ & \multirow{4}{*}{-} & \multirow{4}{*}{0.458} \\
\hline Containers inside the facility & 460 & $173(37.6)$ & & \\
\hline Containers inside and outside the facility & 220 & $96(43.6)$ & & \\
\hline Containers outside the facility & 80 & $31(38.8)$ & & \\
\hline \multicolumn{5}{|l|}{ Cat access to water } \\
\hline Yes & 400 & $161(40.3)$ & \multirow{2}{*}{$1.01(0.78-1.29)$} & \multirow{2}{*}{0.491} \\
\hline No & 800 & $320(40.0)$ & & \\
\hline \multicolumn{5}{|l|}{ Quarantine } \\
\hline Yes & 400 & $124(31.0)$ & \multirow{2}{*}{$0.53(0.41-0.68)$} & \multirow{2}{*}{0.000} \\
\hline No & 781 & $357(45.7)$ & & \\
\hline \multicolumn{5}{|l|}{ Reproductive disorders } \\
\hline Yes & 680 & $276(40.6)$ & \multirow{2}{*}{$1.04(0.82-1.33)$} & \multirow{2}{*}{0.363} \\
\hline No & 520 & $205(39.4)$ & & \\
\hline
\end{tabular}

Table 4 - Logistic regression analysis on risk factors associated with infection by T. gondii in sheep flocks in the state of Sergipe - 2011-2012

\begin{tabular}{lccc}
\hline \multicolumn{1}{c}{ Variable } & p value & OR & $\mathbf{9 5 \% ~} \mathbf{~ I ~}$ \\
\hline Eastern region & 0.001 & 1.61 & $1.20-2.15$ \\
Subsistence system & 0.000 & 3.03 & $1.97-4.68$ \\
Reproduction purpose & 0.008 & 1.65 & $1.13-2.39$ \\
Semi-extensive system & 0.012 & 1.90 & $1.01-3.74$ \\
Waterlogged & 0.005 & 1.81 & $1.19-2.77$ \\
No disinfection & 0.003 & 1.46 & $1.13-1.88$ \\
No dunghill & 0.000 & 1.60 & $1.26-2.03$ \\
No quarantine & 0.000 & 1.87 & $1.45-2.41$ \\
Food in uncovered place & 0,000 & 1.74 & $1.33-2.27$ \\
Cat access in food storage & 0.019 & 1.37 & $1.05-1.80$ \\
\hline
\end{tabular}

\section{Discussion}

In the present study, $93.3 \%$ of the herds had at least one sheep that was T. gondii-positive. The eastern region showed the highest number of foci $(\mathrm{p}=0.001)$, and also held the municipalities with the highest percentage of reactive sheep (Divina Pastora, 73.3\%; and Arauá, 71.7\%). Mendonça et al. (2013) also detected higher percentage of positive samples in the eastern region of Sergipe (32.28\%).

In addition to high temperatures, the eastern, semiarid, and backland regions are characterized as having wet, semiarid, and dry weather, respectively. The predominance of reactive sheep and foci in the eastern region could be related to its weather conditions. Places with low humidity and high temperatures are unfavorable for oocysts (DUBEY, 2010). Nonetheless, although the backlands had the least suitable environment for survival of the agent, cat feces (YILMAZ; HOPKINS, 1972) and soil (FRENKEL et al., 1975) both have the capacity to create microclimates suitable for oocyst development, thus enabling transmission of the agent and continuity of its life cycle.

IFAT showed antibodies titers of 64 in $83.2 \%$ of the sheep. The high number of sheep presenting the minimum titer 
suggests that chronic infection by coccidia was present, as observed in similar studies on sheep in the states of Alagoas and Rio de Janeiro (PINHEIRO et al., 2009; LUCIANO et al., 2011). Mendonça et al. (2013), in the state of Sergipe (11.8\%), and Brandão et al. (2009), in the state of Maranhão (40.5\%), detected high percentages of seropositivity with a titer of 256, therefore slightly higher than in the present study (5.2\%). In another study, titers higher than 1024, suggesting active infection (DUBEY; KIRKBRIDE, 1989), were detected in 21 (4.46\%) out of 481 reagent sheep.

Farming under a subsistence system involved less technology and presented major deficiencies of hygiene, which made it more favorable towards maintenance of the agent $(p=0.000)$. Moreover, cats were commonly present in the farms studied, and this was an important risk factor for infection $(\mathrm{p}=0.000)$.

Flock rearing for reproduction was also found to be a risk factor $(\mathrm{p}=0.008)$. Transmission of $T$. gondii through semen has been reported amongst dogs (ARANTES et al., 2009) and sheep (DE MORAES et al., 2010). However, the epidemiological importance of this infection route is limited, since only males that are used in natural mating and that are in the acute phase of the disease, with tachyzoites multiplying, could have a chance of transmitting the parasite during copulation. Presence of infection showed associations with use of a semi-extensive system and with presence of waterlogged terrain, with risks of infection that were 1.9 and 1.81 times higher, respectively. Pinheiro et al. (2009) observed the same association in relation to the production system. In semi-extensive breeding, the animals are partially confined, thus increasing the risk of contact with cats and sporulated oocysts of T. gondii (MAINAR et al., 1996).

Failure to disinfect the installations and absence of quarantine were also risk factors for infection by T. gondii. Places without proper hygiene presented higher risk of infection by oocysts. Silva et al., (2003) also reported the importance of hygiene with regard to sheep breeding in the state of Pernambuco. Absence of quarantine allows infected pregnant females be introduced into herds. Fetal membranes and aborted fetuses are potential sources of infection, since cats or other animals might eat them. Therefore, fetal membranes and aborted fetuses need to be incinerated, so as to prevent the spread of $T$. gondii to the herd.

The availability of feed in an uncovered place was a risk factor detected in this study, and it favored transmission of $T$. gondii to the herds, since feed in this situation can easily be contaminated with cat feces. The presence of cats was also a risk factor for infection in the present study, as previously observed in several other Brazilian studies (ROMANELLI et al., 2007; LOPES et al., 2010; LUCIANO et al., 2011; ANDRADE et al., 2013), including in the state of Sergipe (MENDONÇA et al., 2013).

The present study allows the conclusions that $T$. gondii is found in farms throughout the three mesoregions of the state of Sergipe and that environmental factors and management have an influence on sheep infection.

\section{Acknowledgements}

We would like to thank São Paulo Research Foundation for the financial support for the laboratory analysis. SM Gennari holds a fellowship from $\mathrm{CNPq}$ (Brazil).

D. P.; LIMA, M. M. Frequência de anticorpos antiToxoplasma gondii em propriedades de criação de caprinos e ovinos no estado de Pernambuco. Ciência Animal Brasileira, v. 12, n. 2, p. 291-297, 2011. doi: 10.5216/cab.v12i2.1370.

ARANTES, T. P.; LOPES, W. D.; FERREIRA, R. M.; PIERONI, J. S.; PINTO, V. M.; SAKAMOTO, C. A.; COSTA, A. J. Toxoplasma gondii: Evidence for the transmission by semen in dogs. Experimental Parasitology, v. 123, n. 2, p. 190-194, 2009. doi: 10.1016/j.exppara.2009.07.003.

BISPO, M. S.; FAUSTINO, M. A. D. G.; AlVES, L. C.; SALCEDO, J. H. P.; SOUZA, C. H.; SOUSA,
CORREIA, É. L. B.; FEITOSA, T. F.; SANTOS, F. A.; AZEVEDO, S. S.; PENA, H. F. J.; GENNARI, S. M.; MOTA, R. A.; ALVES, C. J. Prevalence and risk factors for Toxoplasma gondii in sheep in the State of Paraíba, Northeastern Brazil. Revista Brasileira de Parasitologia Veterinária, v. 24, n. 3, p. 383-386, 2015. doi: 10.1590/ S1984-29612015043. 
DE FARIA RODRIGUES, J. D.; DE MENDONÇA, R. P.; SOARES, V. E.; COSTA, A. J. Seroprevalence of and risk factors for Toxoplasma gondii in sheep raised in the Jaboticabal microregion, São Paulo State, Brazil. Research in Veterinary Science, v. 88, n. 1, p. 104-106, 2010. doi: 10.1016/j.rvsc.2009.06.006.

DE MORAES, E. P. B. X.; BATISTA, A. M.; FARIA, E. B.; FREIRE, R. L.; FREITAS, A. C.; SILVA, M. A. R.; BRAGA, V. A.; MOTA, R. A. Experimental infection by Toxoplasma gondii using contaminated semen containing different doses of tachyzoites in sheep. Veterinary Parasitology, v. 170, n. 3-4, p. 318-22, 2010. doi: 10.1016/j.vetpar.2010.02.017.

DUBEY, J. Toxoplasmosis of animals and humans. 2. ed. Boca Raton: CRC Press, 2009. 336 p.

DUBEY, J. P.; KIRKBRIDE, C. A. Enzootic toxoplasmosis in sheep in north-central United States. The Journal of Parasitology, v. 75, n. 5, p. 673-676, 1989. doi: $10.2307 / 3283047$.

FRENKEL, J. K. Toxoplasmosis in human beings. Journal of the American Veterinary Medical Association, v. 196, n. 2, p. 240-248, 1990.

FRENKEL, J. K.; RUIZ, A.; CHINCHILLA, M. Soil survival of toxoplasma oocysts in Kansas and Costa Rica. The American Journal of Tropical Medicine and Hygiene, v. 24, n. 3, p. 439-443, 1975. doi: 10.4269/ ajtmh.1975.24.439.

FREYRE, A.; BONINO, J.; FALCON, J.; CASTELLS, D.; CORREA, O.; CASARETTO, A. The incidence and economic significance of ovine toxoplasmosis in Uruguay. Veterinary Parasitology, v. 81, n. 1, p. 85-88, 1999. doi: 10.1016/S0304-4017(97)00069-1.

GARCIA, J. L.; NAVARRO, I. T.; OGAWA, L.; OLIVEIRA, R. C. Soroprevalência do toxoplasma gondii, em suínos, bovinos, ovinos e equinos, e sua correlação com humanos, felinos e caninos, oriundos de propriedades rurais do norte do Paraná-Brasil. Ciência Rural, v. 29, n. 1, p. 91-97, 1999. doi: 10.1590/S0103-84781999000100017.

HOSMER, D.; LEMESHOW, S. Applied logistic regression. New York: John Wiley \& Sons Inc., 1989. 307 p.
INSTITUTO BRASILEIRO DE GEOGRAFIA E ESTATÍSTICA (IBGE). Produção da pecuária municipal. 2011. Available from: < https:/goo.gl/bMVD53>. Viewed: 20 June 2017.

LOPES, W. D. Z.; SANTOS, T. R.; DA SILVA, R. S.; ROSSANESE, W. M.; DE SOUZA, F. A.; LUCIANO, D. M.; MENEZES, R. C.; FERREIRA, L. C.; NICOLAU, J. L.; NEVES, L. B.; LUCIANO, R. M.; DAHROUG, M. A. A.; AMENDOEIRA, M. R. R. Soroepidemiologia da toxoplasmose em caprinos e ovinos de três municípios do estado do Rio de Janeiro. Pesquisa Veterinária Brasileira, v. 31, n. 7, p. 569-574, 2011. doi: 10.1590/S0100736X2011000700004.

MAINAR, R. C.; DE LA CRUZ, C.; ASENSIO, A.; DOMÍNGUEZ, L.; VÁZQUEZ-BOLAND, J. A. Prevalence of agglutinating antibodies to Toxoplasma gondii in small ruminants of the Madrid region, Spain, and identification of factors influencing seropositivity by multivariate analysis. Veterinary Research Communications, v. 20, n. 2, p. 153-9, 1996.

MENDONÇA, C. E. D.; BARROS, S. L. B.; GUIMARÃES, V. A. A.; FERRAUDO, A. S.; MUNHOZ, A. D. Prevalence and risk factors associated to ovine toxoplasmosis in northeastern Brazil. Revista Brasileira de Parasitologia Veterinária, v. 22, n. 2, p. 230-234, 2013. doi: 10.1590/ S1984-29612013000200042.

MILLAR, P.; VICENTE, H.; SOBREIRO, R.; COSTA, T.; CARLI, A.; AMENDOEIRA, L.; REIS, M. Soroprevalência de anticorpos anti-Toxoplasma gondii em trabalhadores de um matadouro de suínos e em indivíduos com outras atividades na cidade de Palmas, Paraná, Brasil. Ciência Rural, v. 37, n. 1, p. 292-295, 2007. doi: 10.1590/S010384782007000100050 .

OGAWA, L.; NAVARRO, I. T.; FREIRE, R. L.; OLIVEIRA, R. C.; VIDOTTO, O. Ocorrência de anticorpos antiToxoplasma gondii em ovinos da região de Londrina no Estado do Paraná. Semina: Ciências Agrárias, v. 24, n. 1, p. 57-62, 2003. doi: 10.5433/1679-0359.2003v24n1p57.

PINHEIRO, J. W.;MOTA, R. A.; DA FONSECA OLIVEIRA, A. A.; FARIA, E. B.; GONDIM, L. F. P.; DA SILVA, A. V.; ANDERLINI, G. A. Prevalence and risk factors associated 
to infection by Toxoplasma gondii in ovine in the State of Alagoas, Brazil. Parasitology Research, v. 105, n. 3, p. 709-715, 2009. doi: 10.1007/s00436-009-1472-3.

ROMANELLI, P. R.; FREIRE, R. L.; VIDOTTO, O.; MARANA, E. R. M.; OGAWA, L.; DE PAULA, V. S. O.; GARCIA, J. L.; NAVARRO, I. T. Prevalence of Neospora caninum and Toxoplasma gondii in sheep and dogs from Guarapuava farms, Paraná State, Brazil. Research in Veterinary Science, v. 82, n. 2, p. 202-207, 2007. doi: 10.1016/j.rvsc.2006.04.001.

ROSSI, G. F.; CABRAL, D. D.; RIBEIRO, D. P.; PAJUABA, A. C. A. M.; CORRÊA, R. R.; MOREIRA, R. Q.; MINEO, T. W. P.; MINEO, J. R.; SILVA, D. A. O. Evaluation of Toxoplasma gondii and Neospora caninum infections in sheep from Uberlândia, Minas Gerais State, Brazil, by different serological methods. Veterinary Parasitology, v. 175, n.3-4, p. 252-259, 2011. doi: 10.1016/j.vetpar.2010.10.017.

SANTOS, G. B.; DE SOUSA, I. F.; BRITO, C. O.; SANTOS, V. S.; BARBOSA, R. J.; SOARES, C. Estudo bioclimático das regiões litorânea, agreste e semiárida do estado de Sergipe para a avicultura de corte e postura. Ciência Rural, v. 44, n. 1, p. 123-128, 2014. doi: 10.1590/S0103-84782013005000148.

SERVIÇO BRASILEIRO DE APOIO ÀS MICRO E PEQUENAS EMPRESAS (SEBRAE).
Ovinocaprinocultura: estudo de mercado - Sergipe Potencial de consumo de carne, leite e derivados. 2011.

SILVA, A. V.; CUNHA, E. L. P.; MEIRELES, L.; GOTTSCHALK, S.; MOTA, R. A.; LANGONI, H. Toxoplasmose em ovinos e caprinos: estudo soroepidemiológico em duas regiões do Estado de Pernambuco, Brasil. Ciência Rural, v. 33, n. 1, p. 115-119, 2003. doi: 10.1590/S0103-84782003000100018.

SILVA, K. L. M. D. V.; LA RUE, M. L. Possibilidade da transmissão congênita de Toxoplasma gondii em ovinos através de seguimento sorológico no município de Rosário do Sul, RS, Brasil. Ciência Rural, v. 36, n. 3, p. 892-897, 2006. doi: 10.1590/S0103-84782006000300025.

UENO, T. E. H.; GONÇALVES, V. S. P.; HEINEMANN, M. B.; DILLI, T. L. B.; AKIMOTO, B. M.; DE SOUZA, S. L. P.; GENNARI, S. M.; SOARES, R. M. Prevalence of Toxoplasma gondii and Neospora caninum infections in sheep from Federal District, central region of Brazil. Tropical Animal Health and Production, v. 41, n. 4, p. 547-552, 2009. doi: 10.1007/s11250-008-9220-8.

YILMAZ, S. M.; HOPKINS, S. H. Effects of different conditions on duration of infectivity of Toxoplasma gondii oocysts. The Journal of Parasitology, v. 58, n. 5, p. 938 939, 1972. doi: 10.2307/3286589. doi: 10.2307/3286589. 